\title{
APPEARANCE AND APPLIANCE OF THE TWIN-CITIES CONCEPT ON THE RUSSIAN-CHINESE BORDER
}

\author{
E.V. Mikhailova a,
}

\author{
${ }^{\text {a }}$ National Research Institute - Higher School of Economics, Faculty of Public and Municipal Administration, \\ Department of Territorial Development and Regional Planning, 101000, Moscow, Russia - mikhaylovaev@yandex.ru
}

KEY WORDS: Trans-border agglomeration, Twin-cities, Border Cities, Intermunicipal Cooperation, Territorial Development of the Borderland, Media coverage of Cross-border cooperation, Russian-Chinese borderland

\begin{abstract}
:
The article is devoted to the city pair of Blagoveshchensk (Russia) and Heihe (People's Republic of China), the only city pair in Russian-Chinese borderland that describes itself with the term "twin-cities". The current contribution reconstructs the history of appearance of the twin-cities concept in Russian-Chinese agenda. On the basis of interviews and questionnaires collected in the cities in question the paper examines specificity of understanding of "twin-cities" concept and its practical execution in the Asian context. Exploring the extent to which the twin-cities relations model is applicable to Russian-Chinese border cities, the author concludes that cooperation predominantly exists in a form of bilateral annual events in various spheres (culture, education, sport, etc.) and dialog between delegations of region's/city's representatives, not in a form of direct people-to-people or institution-to-institution cooperation. The lack of local initiatives to cooperate (almost zero-amount of initiatives not from region's/city's administrations) is named as a main drawback of Blagoveshchensk and Heihe relations. While planned character of cooperation makes the calendar of joint events stable and predictable, it also keeps Russian-Chinese cooperation staying on the ritual level and prevents it to become a necessary part of everyday life.
\end{abstract}

\section{INTRODUCTION}

The destiny of developing Russian Far East in general and the Amur Oblast in particular has been an urgent issue for last decades. The most frequently discussed topic usually is its role in the global division of labour. Currently the Amur Oblast government named tourism as one of the tools for diversification of the regional economy (Postanovlenie Pravitel'stva Amurskoi oblasti, 2011). In the search for touristic attractiveness of Blagoveshchensk, the centre of the Amur Oblast, the concept of «twin-cities» with the Chinese city of Heihe on the other bank of the Amur River was put forward (Kontseptsiya razvitiya goroda Blagoveshchenska, 2013).

\section{CONCEPTUAL FRAMEWORK}

The paper examines the issue of twin-cities using this term in a narrow sense, with geographical proximity as an important criterion (as opposed to the broad sense of the twin-cities where the distance between cooperating cities doesn't matter).

It is assumed that entering into the twinning relations implies creating an agglomeration or as figuratively Pertti Joenniemi and Alexander Sergunin said applying the term "twin-cities" by cities indicates that "two aspire to become one" (Joenniemi, P. \& A. Sergunin, 2011). Pooling resources gives access to the economy of scale effect which helps to cut double costs and thus to get a mutual benefit.

The author's approach to interpreting border areas relies on admitting the fact of their coexistence simultaneously within a united transborder space and in various administrative and socio-cultural environments of neighbouring states (Mikhailova, 2013). In the most visually imposing way such systems could be observed in cities, divided by the border as the city-pair of Blagoveshchensk and Heihe is.

\section{METHODS}

The paper relies on academic literature and research fieldwork in the selected cities. The fieldwork was aimed to explore two layers of perception of relations between Blagoveshchensk and Heihe - an expert perspective based on the interviews of people who are involved in carrying out cross-border activities within their professional duties and residents' opinion extracted from filled in questionnaires.

The article is built on analysis of sixty questionnaires (fifty from Blagoveshchensk residents and ten from Heihe residents) and eight interviews (four from Blagoveshchensk experts and four from Heihe experts). The objective shortcoming of the fieldwork is that it was done only with Russian speaking respondents and lacks opinions of Heihe residents who don't speak Russian.

The analysed sections of the author questionnaire comprise of four units - 1) awareness of the concept "Twin Cities"; 2) attitude towards the city on the other side of the border; 3) perception and evaluation of collaboration between cities and 4) expectations and proposals for cooperation between Blagoveshchensk and Heihe.

Due to low amount of collected questionnaires in Heihe, only qualitative analysis is applied to them in the paper. Questionnaires of Blagoveshchensk residents are interpreted both quantitatively and qualitatively.

Interviewees included state representatives (regional and municipal servants), experts working in the field of mass media and higher education. Seven out of eight interviewees for ethical reasons are cited anonymously with using the author system of coding. The list of interviewed organizations is in the appendix 1 . The explanation of the author's coding system is available in appendix 2. 


\section{5 - 6 December 2013, Beijing, China}

\section{GEOGRAPHIC SPREAD OF THE TWIN-CITIES CONCEPT}

Originally, the term "twin cities" came into existence to describe the American pair of cities Minneapolis and St. Paul, located on different sides of the domestic U.S. border. Both cities are located in the Minnesota State. While a less populated St. Paul is the administrative center of this U.S. State, Minneapolis keeps the status of the biggest city in Minnesota. Together they comprise an agglomeration known as "TwinCities".

In course of time, the concept "twin cities" began to be a characteristic for cities, separated by the outer boundary of the states. Particularly demanded this theoretical construct became in European continent from the beginning of 90s (Joenniemi, P. \& A. Sergunin, 2013). The model of "twin cities" was widely interpreted as a "laboratory of European integration" (Schultz, 2002). According to this concept, twinned cities should turn into platforms for implementation of pilot projects for the equalization of regional development and thereby serve as examples of multilateral cooperation.

\section{APPEARANCE OF TWIN-CITIES CONCEPT IN RUSSIAN-CHINESE BORDERLAND}

Appearance of the term "twin-cities" in Asian continent is slow because the concept itself is a western model. For example, there are several paired border settlements on the Sino-Russian borderland - all of them are located in immediate proximity to each other and are separated with the Russian-Chinese state border but nowadays only city pair of Blagoveshchensk and Heihe is trying to use the model of "twin-cities" to describe their relations and refer to some commonality of interests.

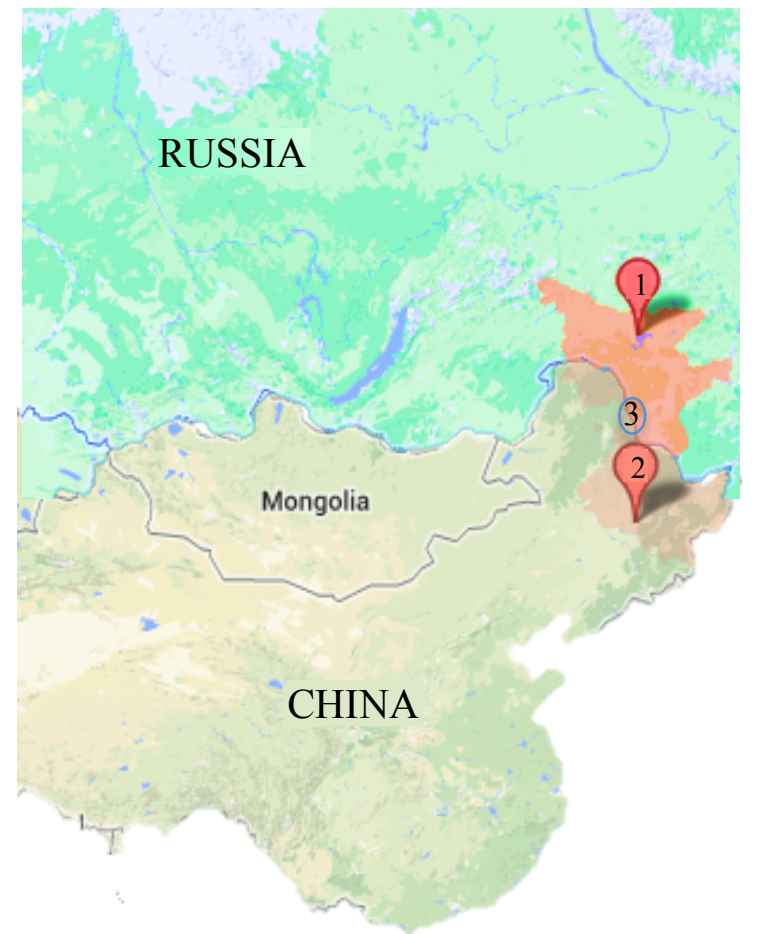

Figure 1. Map of Russian-Chinese borderland (Author)

1 - Amur Oblast (Russia)

2 - Heilongjiang Province (China)

3 - City pair of Blagoveshchensk and Heihe
In academic literature various terms are used to define relationship between a city pair of Blagoveshchensk and Heihe but the most common version is either "border cities" (Yangduo 2004, Xengwei 2007, Ryzhova 2008, Burashnikov 2011) or "twin cities" (Press Service of the Consulate General of People's Republic of China in Khabarovsk 2005, Ryzhova 2009, Chinese Internet Information Centre 2011).

All experts interviewed on the Russian side of the border underlined that the term "twin-cities" was suggested by Chinese. The time of dating this fact varies between period fiveten years ago (2009 and 2003 respectively).

The Chinese expert interviewees named 2005 as the year of appearance of the "twin-cities" concept on the agenda of the Heihe municipal government. That year was marked by the visit of Wang Zhigan, a prominent Chinese journalist to whom the authorship of idea to use the "twin-cities" for branding of Heihe is attributed. The concept got a new slogan - "Two countries, one city" and mainly is expected to come true within economic and humanitarian cooperation. In 2006-2007 the idea of the twin-cities was proposed to the Russian side but it hasn't gained support for that time (interviewee E).

Although Russian side didn't agree to apply the term "twincities" to Blagoveshchensk and Heihe, in 2007 the municipal government of Heihe invited the representatives of Blagoveshchensk municipal administration and Amur Oblast administration to visit the festival "Summer of Twin-Cities". In that time the term got publicity in local (Leto gorodovbliznezov, 2007), regional (Heihe hochet stat' bliznezom Blagoveshchenska, 2007) and national mass media (Priamurye i Kitay gotovyat festival prigranichnyh gorodov, 2007) for the first time.

The interest to use the "twin-cities" as a brand has come back to the Russian-Chinese negotiations agenda in 2011 when during the trilateral Russian-Chinese-Mongolian Tourism Forum in Manchuria the project of reconstructing the central embankment in Blagoveshchensk was presented (Kuzmina, 2011). Nowadays this project is known as the "Golden Mile" project.

Today the "Golden Mile" project is one of the most significant investment project of the Amur Oblast in the field of tourism and the main (and the only official) context of using the term "twin-cities" to Blagoveshchensk and Heihe on the Russian side. The project was presented to Russian Government in January 2013 (Shuvalovu v Priamur'e predstavili proekty, 2013) but still didn't get the federal approval. Interviewees on the Chinese side were unconfident about the exact content of the project and claimed that they wait till the project is officially approved (interviewee E).

\subsection{Portraits of two cities in question and their disparities}

Blagoveshchensk and Heihe are two cities divided with 800 meters of the Amur River which at this area coexists with the Russian-Chinese state border. Thus, one could say that Blagoveshchensk and Heihe in terms of their geographical position represent a traditional example of twin-cities directly facing each other.

Blagoveshchensk is the administrative centre of the Amur Oblast and the fifth biggest city in Russian Far East - from the end of 1980s the city keeps its population a bit higher than 200000 inhabitants: by 2008 the population of Blagoveshchensk was 212500 inhabitants (Kontseptsiya 
razvitiya goroda Blagoveshchenska do 2020 goda, 2008). The city of Heihe is a new centre of Nort-Eastern China and during last 20 years is experiencing a remarkable growth which by now has resulted in around 170000 inhabitants (interviewee F). The city of Heihe is an administrative centre of the Heihe urban district, one of eleven urban districts in the Heilongjiang Province. Thus, despite relatively close number of population two cities have two strong asymmetries - in statuses and character of urban development.

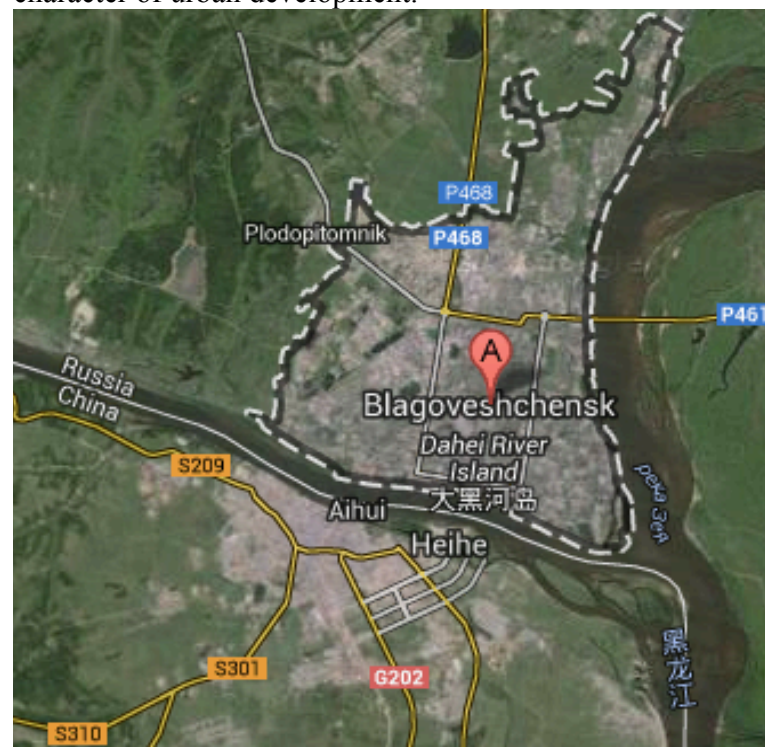

Figure 2. Map of Blagoveshchensk and Heihe

As it was stated in interview B, the Russian-Chinese crossborder cooperation could be better understood if one pays attention to a contradiction between inertness from the Russian side of the border and an abundance of initiatives coming from the Chinese side.

One of reasons for such intense activity of China was named a clear through structure of the Chinese Foreign Affairs Office that works with a formula "signal from the centre - the initiative on the ground." For example, the Chinese Foreign Affairs Office in Heihe is an authority with double subordination - as it combines complying the policies of both municipality and the Office of Foreign Affairs in Beijing.

Russian municipalities don't have any planned interaction with Russian Ministry of Foreign Affairs that's why all ideas of joint development of border cities are difficult to implement (interviewee B). As practice shows, in Russian context projects of creating a transborder agglomeration usually are cascaded from above or vice versa should get the authorization from the centre.

\section{TWIN-CITIES AS A STRATEGY OF TOURISTIC ATTRACTIVENESS}

On Chinese side the term "twin-cities" has been widely used for place promotion of Heihe in China since 2005 and could be assessed as a success story if we consider that in 2013 Heihe was visited by 4 million of Chinese tourists.

Blagoveshchensk has more modest results: as the Minister of Foreign Economic Relations, Tourism and Business of the Amur Oblast Igor Gorevoy mentioned in the interview to the author, in 2012 the city had 38000 Chinese tourists which equals $15 \%$ of all Chinese tourists received in Russia in that year.

Amount of Chinese tourists is dominating in the flow of international incoming tourists in Amur Oblast for a long time since Blagoveshchensk has lost the status of the closed city. Till 2005 the main touristic attraction of the Amur Oblast's centre for Chinese was gambling. After the national ban to have slot machines the tourist flow from China has decreased almost twice and reached the point of 10000 people per year. By 2010 the number of Chinese tourists came back to 20000 people. The cooperation programs are named as a crucial instrument for revitalizing the touristic flow from China to Russia (Postanovlenie Pravitel'stva Amurskoi oblasti, 2012).

Although these numbers don't look convincing enough, the Amur Oblast administration treats touristic industry as the potential provider of sound income for regional and municipal budgets in 20-30 years. The argumentation for this is that tourism as an industry of producing impressions allows entering the huge Chinese market without competition because if a person wants to visit Russia - he or she should cross to Russia (interview A). While production of any goods is cheaper in China, none "Russian village"* could be compared to experience of visiting Russia itself.

$6 \%$ of Blagoveshchensk respondents have never been to Heihe, while other $94 \%$ from time to time are visiting the other bank of the Amur River. The majority of those who go to Heihe, cross the Russian-Chinese border couple of times per year $(60 \%)$, other $30 \%$ go several times per month, $6 \%$ several times per week and $4 \%$ couple of times per day. As a purpose of visiting Heihe $74 \%$ of Blagoveshchensk respondents named tourism and $46 \%$ - shopping (it was a multiple choice question where respondent were allowed to select several variants).

There is also a psychological issue on the frequency of exchanging visits between these twin-cities: as we can see from the survey, Russians go to Heihe to feel abroad, to change the scene, to consume goods and services of other origin, while according to interview E, F and G, an average Chinese resident doesn't go abroad frequently or even hasn't been abroad (for better understanding interviewees used an example that if a Chinese person have been abroad it is considered a great achievement and a fact to be proud of). If a Heihe resident doesn't have to cross the Russian-Chinese border because of work or studying on the Russian side, with high probability we can say that if he or she has resources to cross the border, he or she will visit Blagoveshchensk once while Blagoveshchensk residents in general go to Heihe on relatively regular basis treating this activity a part of their annual life routine.

As interviewees $\mathrm{E}$ and $\mathrm{H}$ pointed out, the main cause for incoming migration to Heihe is work-related issues - people are coming either due to relocation of the organization they are working for (the relocation of the power plant of the city Bei'an to Heihe could be shown as an example) or due to their search for a better life. The last category of adventurers contains people both from other Northern-Eastern and Southern provinces of China. Many of them don't succeed in adapting to the Northern weather and climate, give up seeking for their fortune and go back to their home places. Such a rapid increase

\footnotetext{
* So called «Russian village» was built in a distance of $20 \mathrm{~km}$ from Heihe city centre as a venue for filming a movie «A zori zdes' tikhie» [“The Dawns Here Are Quiet”].
} 


\section{5 - 6 December 2013, Beijing, China}

of population and intense migration flows mean that almost everybody is relatively new in Heihe.

Thus, Russian population base visiting Heihe is quite stable while Chinese people visiting Blagoveshchensk are mostly changing. In other words, we can't expect Blagoveshchensk and Heihe to follow the traditional European "twin-cities" pattern when two cities represent two constant audiences visiting each other from time to time and making stable contacts on the other side of the border.

According to the conducted survey, the residents of Heihe appreciate in Blagoveshchensk its cleanness, fresh air and politeness of its dwellers. The residents of Blagoveshchensk among considerable features of Heihe named low prices of goods and wide variety of available services, different culture, good roads, everything in order and possibility to take inexpensive flights to other touristic destinations.

Answering the question of priorities of cooperation between Blagoveshchensk and Heihe, Chinese respondents named culture and transport while Russian respondents named trade and tourism. Both Russian and Chinese named education as another substantial field of cooperation.

"Trade", "market" and "entrepreneurs" were named as the main engines of cooperation between Blagoveshchensk and Heihe by Russian respondents, while Chinese respondents named "municipal and regional administrations".

These facts reflect two different approaches to interpret cooperation. During last 20 years of market economy Russians get used to respect natural character of economic cooperation even though the chief dimension of Blagoveshchensk participation would be transit and trade broker roles. Planned economy of People's Republic of China and its hierarchical structure of decision-making has taught Chinese residents to underline the importance of administrative bodies as actors which initiate or give authorization for all economic activities.

\section{ROLE OF MASS MEDIA IN POPULARIZATION OF TWIN-CITIES RELATIONS}

$52 \%$ of Blagoveshchensk respondents wrote that they have come across the term "twin-cities" before filling in the questionnaire but only $4 \%$ said that they applied this term to Blagoveshchensk and Heihe city pair. $24 \%$ of respondents who know the term have learned about twin-cities from the Internet, while $43 \%$ from TV.

In general it is fair to say that media coverage of relations between Blagoveshchensk and Heihe usually followed the dialog of three administrations: Amur Oblast, Blagoveshchensk municipality and Heihe municipality.

The Amur River flood of August 2013 brought attention of Russian audience both to Blagoveshchensk and Heihe simultaneously. It was almost the first time when two cities were put forward in the Russian national media together without administrative support.

The flood of the Amur River in August 2013 added a new dimension to Russian-Chinese negotiations - namely, the necessity of cooperation with China to prevent and overcome natural disasters. As a result, the recent dialog between Russian and Chinese companies responsible for water management in the region was focused on building a joint Russian-Chinese flood-resistant hydropower plant on one of tributaries of the Amur river (Rusgidro and San'sya obsuzhdayut protivopavodkovye GES na pritokah Amura, 2013). This initiative of uniting efforts could add a new role to the cooperation between two border cities - Blagoveshchensk and Heihe.

\subsection{CONCLUSIONS}

The article has proved that the term "twin-cities" was brought to the Russian-Chinese agenda by Chinese in 2006 and got support from the Russian authorities only in 2011. The expert interviews have shown that the term doesn't satisfy either Russian or Chinese party and is used by them in different contexts for their own purposes. Thus, the consent on using the term "twin-cities" doesn't come into place between Blagoveshchensk and Heihe.

Exploring the extent to which the twin-cities relations model is applicable to Russian-Chinese city pair of Blagoveshchensk and Heihe, the author concludes that cooperation predominantly exists in a form of bilateral annual events in various spheres (culture, education, sport, etc.) and dialog between delegations of region's/city's representatives, not in a form of direct institution-to-institution or people-to-people cooperation which is the main feature of twinning relations in European context.

Relying on the fieldwork in Blagoveshchensk and Heihe, the author admits high influence of region's/city's administration in maintaining interaction between cities. The lack of local initiatives to cooperate (almost zero-amount of initiatives not from region's/city's administrations) is named as a main drawback of Blagoveshchensk and Heihe relations. While planned character of cooperation makes the calendar of joint events stable and predictable, it also keeps Russian-Chinese cooperation staying on the ritual level and prevents it to become a necessary part of everyday life.

On the other hand, the recent discussion on the uniting efforts for overcoming natural disasters could be seen as the first initiative to cooperate not close to the border but across the borders.

\section{References}

Burashnikov, D., 2011. The specificity of interaction between two cultures in the area of border cities of Blagoveshchensk (Russia) and Heihe (China). P. 50-54. Uchenye zapiski Komsomol'skogo-na-Amur tekhnicheskogo universiteta [Academic notes of the Technical University of Komsomolskna-Amure]. \# IV-2 (8). http://www.uzknastu.ru/files/pdf/20118-2/50-54.pdf (16 Sep. 2013)

(2011) Chinese-Russian cross-border project "Twin Cities" will promote cooperation between the two countries. Xinhua News Agency. The Chinese Internet Information Centre. http://russian.china.org.cn/news/txt/2011-

06/19/content_22813465.htm (17 Sep. 2013)

(2005) Heihe and Blagoveshchensk are the first and so far the only "twin cities" on the Sino-Russian border. The official website of the Consulate General of People's Republic of China in Khabarovsk.

http://www.chinaconsulate.khb.ru/rus/xwdt/t200696.htm 
(2007) Heihe hochet stat' bliznezom Blagoveshchenska [Heihe wants to become a twin of Blagoveshchensk]. Amurskaya Pravda \# 125 (26213), Blagoveshchensk, Russia.

http://www.ampravda.ru/2007/07/13/013639.html (20 Oct. 2013).

Joenniemi, P. \& A. Sergunin, 2013. Kirkenes-Nikel: Catching a Second Wind of Twinning? Arctic Yearbook 2012-2013. http://arcticyearbook.com/images/Articles_2013/JOENNIEMI_ SERGUNIN\%20AY13\%20FINAL.pdf (20 Oct. 2013).

Joenniemi, P. \& A. Sergunin, 2011. When Two Aspire to Become One: City-Twinning in Northern Europe. Journal of Borderlands Studies. 26:2, pp. 231-242. Routledge Journals, Taylor \& Francis Group, UK.

(2013) Kontseptsiya razvitiya goroda Blagoveshchenska kak mezhdunarodnogo rossijsko-kitajskogo tsentra kongressnovystavochnoy deyatel'nosti - investitzionny proekt "Zolotaya milya". [Conception of developing Blagoveshchensk as a centre of international Russian-Chinese exhibitions and congresses the investment project "Golden Mile"] (14 May 2013).

(2008) Kontseptsiya razvitiya goroda Blagoveshchenska do 2020 goda, utverzhdennaya postanovleniem mera Blagoveshchenska \# 2164. [Conception of developing Blagoveshchensk till 2020 adopted under the order \#2164 of the Blagoveshchensk's mayor.] (13 Apr. 2013).

Kuzmina, E. 2011. Blagoveshchensk y Heihe pobyvali $v$ Man'chzhurii [Blagoveshchensk and Heihe have been to Manchuria]. Amurskaya Pravda \# 92 (27155), Blagoveshchensk, Russia.

http://www.ampravda.ru/2011/05/26/030351.html (22 Oct. 2013).

(2007) "Leto gorodov-bliznezov" proydet v Heihe [The "Summer of Twin-Cities" will take place in Heihe], Municipal informational agency "Gorod", Blagiveshchensk, Russia. http://tvgorod.ru/2375-«Leto_gorodov-

bliznecov»_projdet_v_Xejxe.html (20 Oct. 2013).

Mikhailova, E., 2013. The Role of the Transborder Territorial Unit of Blagoveshchensk and Heihe in Russian-Chinese CrossBorder Cooperation. In: Russia and China: history and perspectives of cooperation. The Collection of articles presented on the International conference in BlagoveshchenskHeihe-Harbin, May 15-20, 2013. Blagoveshchensk, Russia.

(2011) Postanovlenie Pravitel'stva Amurskoi oblasti ot 23.09.2011 N 616 "Ob utverzhdenii dolgosrochnoy tselevoy programmy "Razvitie turizma I etnokulturnogo naslediya $\mathrm{v}$ Amurskoy oblasti na 2012-2016 gody". [The bill \# 616 of the Amur Oblast Government "On adopting the long-term program "Development of tourism and ethno-cultural heritage of the Amur Oblast for 2012-2016”]

http://www.amurobl.ru/wps/portal/!ut/p/c5/04_SB8K8xLLM9 MSSzPy8xBz9CP0os3gTAwN_RydDRwN_S1dDA0_f4GALI wP3ICNLY30v_aj0nPwkoEo_j_zcVP2C7EBFALU8x1Q!/d13/ d3/L2dJQSEvUÜt3QS9ZQnZ3LzZfNDAwT0FCMUEwT0Y4 MDBJVUFKOVJIN0xQSjM!/ (12 Oct. 2013).

(2012) Postanovlenie Pravitel'stva Amurskoi oblasti ot 13.07.2012 №380 “Ob utverzhdenii Strategii sozial'noekonomicheskogo razvitiya Amurskoi oblasti na period do 2025 goda". [The bill \# 380 of the Amur Oblast Government "On adopting the Strategy of socio-economic development till 2025".]

http://www.amurobl.ru/wps/portal/!ut/p/c4/04_SB8K8xLLM9 MSSzPy8xBz9CP0os3gTAwN_RydDRwMLi0AzA09L5yALZ 0_IMsQY_2CbEdFAFEGI94!//(12 Oct. 2013).
(2007) Priamurye i Kitay gotovyat festival prigranichnyh gorodov [The Amur region and China are preparing the festival of border cities] Information Agency «REGNUM», Moscow, Russia. http://www.regnum.ru/news/856419.html (20 Oct. 2013).

(2013) Rusgidro and San'sya obsuzhdayut protivopavodkovye GES na pritokah Amura [RusGydro and San'sya disscussed the flood-resistant hydropower plants on the tributaries of the Amur river] Information agency «RIA Novosti», Moscow, Russia. http://ria.ru/world/20131022/971739196.html (22 Oct. 2013).

Ryzhova, N., 2008. Informal Economy of Translocations. The case of the twin city of Blagoveshensk-Heihe. Inner Asia Journal. Vol. 10. no. 2. pp. 323-351. University of Cambridge, UK.

http://www.nceeer.org/Programs/Carnegie/Reports/07_Ryzhova _Inner_Asia.pdf (29 Sep. 2013)

Schultz, H., 2002. Twin Towns on the Border as Laboratories of European Integration. Frankfurt (Oder): Frankfurter Institut für Transformationsstudien (Arbeitsberichte 4/02). http://www.europa-

uni.de/de/forschung/institut/institut_fit/publikationen/discussion _papers/2002/04-02-Schultz.pdf. (27 Oct. 2013).

(2013) Shuvalovu v Priamur'e predstavili proekty po razvitiyu mezhdunarodnoy aglomeratsii "Blagoveshchensk-Heihe" [International agglomeration of Blagoveshchensk and Heihe was presented to Shuvalov during his visit to the Amur Oblast'] Information agency "Interfax Russia". http://www.interfaxrussia.ru/FarEast/news.asp?id=376517\&sec $=1671$

Xengwei, Z., 2007. Basic Facts on Various Development Zones in the Border Provinces and Regions of China. Policy and Management Mechanisms for Economic Development Areas. Urumqi, Xinjiang Uygur Autonomous Region, People's Republic of China.

Yangduo, Z., 2004. First Opportunities for Construction of Sino-Russian Border Trade Zones Hushi in Heilongjiang Province. Heilongjiang Foreign Economic Relations and Trade. N1. P.35-37.

\section{Appendix 1. \\ List of interviewed organizations}

Organizations interviewed in Blagoveshchensk

1. Ministry of Foreign Economic Relations, Tourism and Business of the Amur Oblast;

2. Unit of Ministry of Foreign Affairs in Blagoveshchensk;

3. Newspaper "Amurskaya Pravda".

Organizations interviewed in Heihe

1. Unit of Ministry of Foreign Affairs in Heihe;

2. Heihe University;

3. Newspaper Heihe Zhibao.

\section{Appendix 2.}

Explanation of interviews' coding

1. Interview A - with Igor Gorevoy, Minister of Foreign Economic Relations, Tourism and Business of the Amur Oblast. Interview by author. Tape recording. 24 minutes. Blagoveshchensk, May 15, 2013.

2. Interview B - Interview by author. Tape recording. 78 minutes. Blagoveshchensk, May 24, 2013. 
The International Archives of the Photogrammetry, Remote Sensing and Spatial Information Sciences, Volume XL-4/W3, 2013 ISPRS/IGU/ICA Joint Workshop on Borderlands Modelling and Understanding for Global Sustainability 2013,

\section{5-6 December 2013, Beijing, China}

3. Interview $\mathrm{C}$ - Interview by author. Tape recording. 36 minutes. Blagoveshchensk, May 14, 2013.

4. Interview D - Interview by author. Tape recording. 31 minute. Blagoveshchensk, May 20, 2013.

5. Interview E - Interview by author. Tape recording. 60 minutes. Heihe, May 16, 2013.

6. Interview $\mathrm{F}$ - Interview by author. Tape recording. 21 minutes. Heihe, May 16, 2013.

7. Interview $\mathrm{G}$ - Interview by author. Tape recording. 16 minutes. Heihe, May 16, 2013.

8. Interview $\mathrm{H}$ - Interview by author. Tape recording. 25 minutes. Heihe, May 17, 2013. 